\title{
PENGGUNAAN COMIC STRIP PADA MATERI FUTURE TENSE: TINDAKAN KELAS PADA MAHASISWA DKV UNIVERSITAS INDRAPRASTA PGRI
}

\author{
Fitria Iswari \\ Dian Handayani \\ Fenti Mariska Yohana
}

Universitas Indraprasta PGRI

TB. Simatupang, JI. Nangka Raya No.58 C, RT.5/RW.5, Tj. Bar., Kec. Jagakarsa, Kota

Jakarta Selatan, Daerah Khusus Ibukota Jakarta 12530

fitriaiswari@gmail.com

Naskah masuk: 30-10-20, direvisi: 29-01-20, diterima: 30-02-20, dipublikasi: 30-04-20

\begin{abstract}
Abstrak: Bahasa Inggris saat ini dapat dikatakan bahasa yang universal karena banyak digunakan sebagai alat komunikasi di pelbagai negara. Salah satunya di Indonesia Bahasa Inggris dipelajari mulai dari tingkat sekolah dasar hingga perguruan tinggi. Dalam bahasa inggris di perguruan tinggi mahasiswa akan mempelajari berbagai macam tenses dan tidak sedikit dari mereka yang merasa kesulitan dalam memahaminya. Salah satu contohnya ialah future tense. Peranan media pembelajaran dalam proses pengajaran sangat penting, apabila mahasiswa masih ada yang merasa kesulitan hal ini menunjukan bahwa media pembelajaran tersebut perlu dikembangkan dibuat lebih menarik. Penelitian ini bertujuan untuk melihat keefektifan media pembelajaran comic strip. Peneliti memilih komik strip karena dianggap komik strip lebih menarik dan lebih sederhana. Metode yang digunakan oleh peneliti ialah penelitian tindakan kelas yang akan dilakukan ujicoba terhadap 3 kelas yang masing - masing kelas terdiri dari 40 mahasiswa, jumlah keseluruhan menjadi 120 mahasiwa. Dalam hal ini peneliti akan melakukan pretest kemudian melakukan tindakan kelas lalu post test guna melihat hasil dari pengunaan comic strip dalam pembelajaran. Pengumpulan data dilakukan dengan nilai tes dan hasil wawancara. Data menunjukan ada peningkatan nilai rata- rata $18 \%$. Kata kunci: Komik Strip, Media pembelajaran, Future tense
\end{abstract}

\begin{abstract}
Todays we can say that English is a universal language because it is used as communication tool in many countries. In Indonesia English is studied from elementary school to college. Student in college will study any kinds of tenses, and some of them face the difficult in understanding it, for example future tense. The role of teaching learning media in teaching process is very important. If there is student who feels the difficulties, it means that the teaching learning media need to be improved and made more interesting. The aim of this research is to find the effectiveness of comic strip. The researchers choose comic strip because they think that comic strip is more interesting and simple than before. Researchers use action research method that will be tested to 3 classes which consist of 40 students from each class, and the total respondent is 120 students. Researchers will take the pretest, action in the class, take the post test to see the result of using the comic strip. The data collection is taken from score and interview. the data shown the increasing $18 \%$.
\end{abstract}

Keywords: Comic strip, teaching and learning media, future tense

\section{PENDAHULUAN}

Saat ini bahasa Inggris dapat dikatakan sebagai bahasa yang Universal karena banyak digunakan sebagai alat komunikasi di pelbagai negara. Hal tersebut menjadi penting dan membuat materi
Bahasa Inggris menjadi salah satu subjek yang dipelajari baik sebagai bahasa ke dua maupun bahasa asing diperbagai negara. Salah satunya di Indonesia Bahasa Inggris menjadi bahasa asing yang dipelajari mulai 
dari tingkat sekolah dasar hingga perguruan tinggi. Dalam pembelajaran Bahasa Inggris terdapat 4 keterampilan yaitu mendengar (listening), membaca ( reading), berbicara (speaking), dan menulis ( writing). Dalam proses pembelajaran di perguruan tinggi 4 keterampilan tersebut diajarkan supaya mahasiswa mampu menguasi bahasa Inggris secara baik.

Dalam kurikulum pada perguruan tinggi Universitas Indraprsata PGRI program studi Desain Komunikasi Visual ( DKV). Materi Bahasa Inggris dipelajari pada semester 1 dan 2. Hal ini bertujuan agar mahasiswa mampu menguasai Bahasa Inggris dengan baik. Dalam mata kuliah Bahasa Inggris 1 mahasiswa akan diberikan materi tata bahasa ( grammar) berupa beraneka macam tenses yang harus mereka pahami. Dari hasil pengamatan selama proses pembelajaran mahasiswa sering menemukan kesulitan dengan materi future tense dalam penggunaan will dan to be going to. Dalam keadaan tersebut maka seringkali pendidik harus memberikan penjelasan dengan berbagai cara salah satunya memberikan contoh melalui role playing ataupun melalui video. Namun dalam kenyataanya masih ada mahasiswa yang kurang paham, ditambah dengan masalah teknis di dalam kelas, seperti listrik padam, kabel penyambung yang tidak bisa dihubungkan, dan mahasiswa yang terkadang malu - malu untuk mempraktikan penggunaan future tense tersebut serta dibutuhkan waktu yang lebih banyak untuk mempraktekan. Hal ini menjadi kendala mengingat mata kuliah ini memiliki bobot 2 sks dengan materi yang begitu banyak, sehingga waktu banyak watu yang terbuang karena penggunaan media pembelajaran yang kurang efisien

Tidak dapat dipungkiri kemajuan teknologi dalam perkembangan zaman saat ini menjadi sebuah tantangan tersendiri bagi para pendidik baik dosen maupun guru dalam memilih media pembelajaran yang sesuai dengan generasi milenial saat ini. dosen sebagai fasilitator para mahasiswa akan selalu berupaya memberikan yang terbaik dalam proses pembelajaran demi tercapainya tujuan dalam pendidikan. Fungsi dan tujuan pendidikan sebagaimna disebutkan dalam Undang-Undang Nomor 20 tahun 2003 pasal 3 dapat tercapai dengan peran serta tenaga pendidik dalam menunjang penyelenggaraan pendidikan yang berkualitas. Dalam proses pembelajaran media memiliki peranan yang cukup penting dan berpengaruh. Seperti studi sebelumnya yaitu artikel yang di tulis oleh Firda Maghfirah dkk (2017)dalam artikelnya teertulis Produk yang dikembangkan dapat meningkatkan motivasi membaca siswa dilihat dari signifikansi sebesar 0,0 dan nilai positive ranks lebih banyak dibandingkan dengan negative ranks, selain itu Nurul Hidayah dan Rifky Khumairo Ulva(2017) menyatakan Secara umum peserta didik menyukai media komik yang dikembangkan dikarenakan media komik dapat sangat membantu saat belajar . Seperti halnya penelitian yang dilakukan oleh Sasti Karmiani dalam artikel yang berjudul Penggunaan Media Komik Berbahasa Inggris Sebagai Upaya Meningkatkan Kemampuan Membaca Pemahaman Bahasa Inggris Pada Kelas VIII SMPN 3 Teluk Kuantan. Menunjukan bahwa terjadi peningkatan dalam kemampuan membaca pemahaman siswa meningkat menjadi 75,23 ( 80,95\%) yang termasuk dalam kriteria baik. Hal tersebut menunjukan penggunaan media yang tepat mampu memberikan hasil yang terbaik.

Dalam pemilihan media pembelajaran harus diperhatikan beberapa ciri media pembelajaran yang baik, seperti yang diungkapkan oleh Arsyad (2013) kriteria yang patut diperhatikan dalam 
memilih media pembelajaran sebagai berikut:

1) Media pembelajaran hendaknya mengusung tujuan yang sesuai dengan apa yang ingin dicapai, mengacu pada salah satu atau gabungan dari dua atau tiga ranah kognitif, afektif, dan psikomotor.

2) Media pembelajaran tepat untuk mendukung isi pelajaran yang sifatnya fakta, konsep, prinsip, atau generalisasi.

3) Media pembelajaran bersifat praktis, luwes, dan bertahan.

4) Guru harus terampil dan mampu menggunakannya dalam proses pembelajaran.

5) Efektif dan tepat digunakan pada pengelompokan sasaran.

6) Mutu teknis visual harus memenuhi persyaratan teknis tertentu.

Berdasarkan latar belakang tersebut peneliti memilih comic strip sebagai media yang digunakan sebagai menggunakan media pe,belajaran baru. Penelitian ini bertujuan untuk meningkatkan proses pembelajaran dan hasil belajar. Comic strip ini telah dibuat dalam penelitian sebelumnya dan akan diujikan dalam penelitian ini. Comic strip ini dibuat hanya satu lembar, mudah dibaca dan diaplikasikan kepada para mahasiswa ataupun siswa dari pelbagai tingkat pendidikan.

\section{METODE}

Penilitian ini dilakukan di Universitas Indraprasta PGRI Jakarta dengan sample mahasiswa program studi Desain Komunikasi Visual pada mata kuliah Bahasa Inggris 1 (General English). Metode dalam penelitian ini ialah action research yang dilakukan selama 3 bulan. Dalam pelaksanaanya penelitian ini menggunakan metode tindakan kelas (action research) untuk melihat pengaruh media comic strip dalam proses dan hasil pembelajaran.
Menurut para ahli salah satunya ialah Menurut Gunawan (2007), action research adalah kegiatan dan atau tindakan perbaikan sesuatu yang perencanaan, pelaksanaan, dan evaluasinya digarap secara sistematik dan sistematik sehingga validitas dan reliabilitasnya mencapai tingkatan riset. Sedangkan menurut Davison, martisons \& Kocks (2004), mengatakan penelitian tindakan kelas, sebagai sebuah cara penelitian yang didirikan atas asumsi bahwa teori dan praktek dapat secara tertutup diintegrasikan dengan pembelajaran dari intervensi yang diencanakan setelah diagnosis terperinci terhadap konteks masalahnya. Sedangkan menurut Sugiyono (2014: 72) menyatakan bahwa penelitian eksperimen dapat diartikan sebagai metode penelitian yang digunakan untuk mencari pengaruh perlakuan tertentu terhadap yang lain dalam kondisi yang terkendalikan.

Dari pendapat para ahli tentang penelitian tindakan kelas, dapat ditarik kesimpulan bahwa penelitian tindakan ialah sebuah penelitian yang berbentuk eksperimen terkendali berlandaskan teori dan asumsi untuk melihat pengaruh dan membuktikan suatu teori yang telah dibuat.

Davison, Martinsons \& Kock (2004), membagi Action research dalam 5 tahapan yang merupakan siklus, yaitu :

1. Melakukan diagnosa (diagnosing)

Dalam proses ini peneliti melakukan identifikasi masalah dengan cara melakukan pre test dan wawancara terhadap topic Future Tense. Dari hasil proses ini terlihat kesulitan yang dihadapi partisipan.

2. Membuat rencana tindakan (action planning.

Peneliti dan partisipan (Mahasiswa) memahami pokok masalah yang ada kemudian dilanjutkan dengan menyusun rencana tindakan untuk menyelesaikan masalah yang ada. Peneliti dalam hal ini memilih menyediakan media pembelajaran 
yang memudahkan mahasiswa dalam memahami materi future tense. Peneliti bersama tim membuat sebuah comic strip sebagai media pembelajaran yang diharapkan mampu mempermudah mahasiswa dalam memahami future tense.

3. Melakukan tindakan (action taking)

Dalam proses ini peneliti melakukan tindakan kelas untuk menguji media pembelajaran yang telah dirancang. Peneliti memilih 3 kelas yang terdiri dari 40 mahasiswa untuk menguji media pembelajaran berupa comic strip. 1 kelas kontrol dan 2 lainnya kelas eksperimen.

4. Melakukan evaluasi (evaluating)

Setelah masa tindakan yaitu dengan cara mengujicoba media pembelajaran baru berupa Comic strip. Peneliti melakukan evaluasi terhadap hasil belajar atas penerapan comic strip di dalam pembelajaran.

\section{Pembelajaran (learning)}

Tahap pembelajaran merupakan tahap akhir dari serangkaian proses dalam penelitian tindakan kelas. Tahap ini merupakan tahap pertimbangan dari hail penelitian yang didapat. Dalam hal ini apakah yang dilaukan selanjutnya terhadap media pembelajaran comic strip.

\section{HASIL DAN PEMBAHASAN}

Sebelum penggunaan comic strip sebagai media pembelajaran, media yang digunakan berupa modul yang dimana terdapat materi berupa berbagai macam tenses, salah satunya yaitu future tense. Seperti diketahui future tense memiliki dual bentuk yaitu : (1) menggunakan will dan (2) menggunakan to be going to, dua bentuk tersebut memiliki makna akan. Dalam penelitian ini peneliti mengambil pre- test guna memberikan gambaran perbedaan hasil sebelum dan sesudah menggunakan comic strip. Dari 7 kelas diambil 3 kelas dengan jumlah masing - masing 40 anak . mereka diberikan 10 pertanyaan mengenai future tense, dan didapat hasil sebagai berikut :

Table 1. hasil pretest mahasiswa

\begin{tabular}{|c|c|c|c|}
\hline No & Kelas A & Kelas B & Kelas C \\
\hline 1 & 30 & 20 & 50 \\
\hline 2 & 60 & 60 & 70 \\
\hline 3 & 60 & 60 & 70 \\
\hline 4 & 70 & 40 & 10 \\
\hline 5 & 60 & 20 & 30 \\
\hline 6 & 70 & 30 & 60 \\
\hline 7 & 70 & 50 & 30 \\
\hline 8 & 70 & 30 & 70 \\
\hline 9 & 70 & 50 & 60 \\
\hline 10 & 70 & 40 & 30 \\
\hline 11 & 70 & 60 & 40 \\
\hline 12 & 80 & 60 & 60 \\
\hline 13 & 65 & 30 & 70 \\
\hline 14 & 75 & 50 & 70 \\
\hline 15 & 70 & 50 & 20 \\
\hline 16 & 75 & 50 & 60 \\
\hline 17 & 40 & 70 & 60 \\
\hline 18 & 70 & 50 & 70 \\
\hline 19 & 70 & 80 & 50 \\
\hline 20 & 75 & 60 & 20 \\
\hline 21 & 50 & 60 & 50 \\
\hline 22 & 70 & 50 & 30 \\
\hline 23 & 70 & 50 & 50 \\
\hline 24 & 70 & 60 & 60 \\
\hline 25 & 70 & 50 & 40 \\
\hline 26 & 70 & 60 & 80 \\
\hline 27 & 60 & 60 & 60 \\
\hline 28 & 70 & 60 & 30 \\
\hline 29 & 80 & 30 & 30 \\
\hline 30 & 80 & 30 & 50 \\
\hline 31 & 70 & 50 & 60 \\
\hline 32 & 50 & 60 & 70 \\
\hline 33 & 70 & 20 & 70 \\
\hline 34 & 70 & 30 & 70 \\
\hline 35 & 70 & 40 & 40 \\
\hline 36 & 50 & 60 & 40 \\
\hline 37 & 40 & 70 & 60 \\
\hline
\end{tabular}




\begin{tabular}{|r|r|r|r|}
\hline 38 & 30 & 60 & 80 \\
\hline 39 & 40 & 40 & 50 \\
\hline 40 & 50 & 60 & 50 \\
\hline Jml & 2550 & 1960 & 2070 \\
\hline $\begin{array}{l}\text { Rer } \\
\text { ata }\end{array}$ & \multicolumn{3}{|c}{54.83333333} \\
\hline
\end{tabular}

Dalam tabel 1 menunjukan bahwa rata - rata hasil yang didapat oleh siswa adalah 54, hal ini menandakan bahwa pemahaman siswa tentang future tense masih rendah.

Seperti yang diungkapkan oleh Syaiful Bahri Djamarah dan Aswan Zain (2006: 122), proses belajar mengajar dengan bantuan media akan mempertinggi kegiatan belajar anak dalam tenggang waktu yang cukup lama. Dengan pertimbangan hal tersebut peneliti memilih comic strip sebagai media pembelajaran pada materi future tense, dikarenakan comic strip benda yang sangat dekat dan cukup familiar dengan kehidupan remaja. Comic strip ini digunakan oleh peneliti untuk menjelaskan materi future tense yang digunakan pada 3 kelas.

\section{Makna dalam comic Strip Materi Future Tense.}

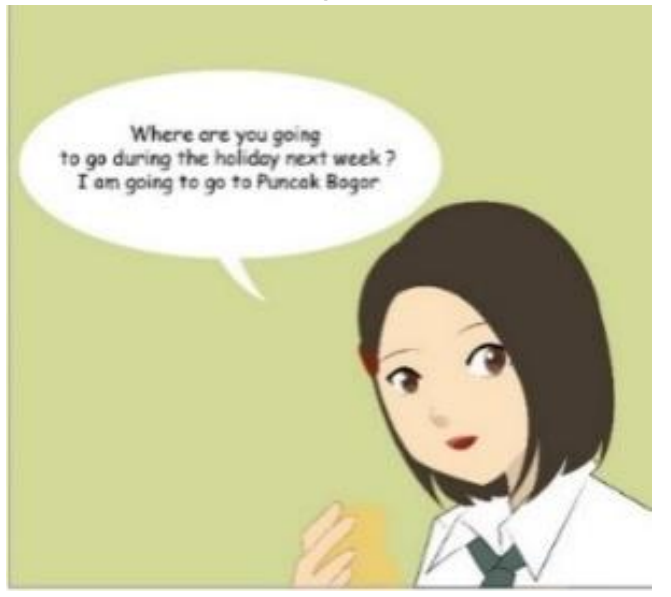

Gambar 1. Future tense (to be going to) Sumber: Pribadi

\section{Pada gambar 1 peneliti} menggunakan to be going to dalam kalimat percakapan yang menunjukan bahwa siswa tersebut merencanakan dengan pasti bahwa dia yakin akan menghabiskan waktu liburan ke Puncak dan akan terealisasi.

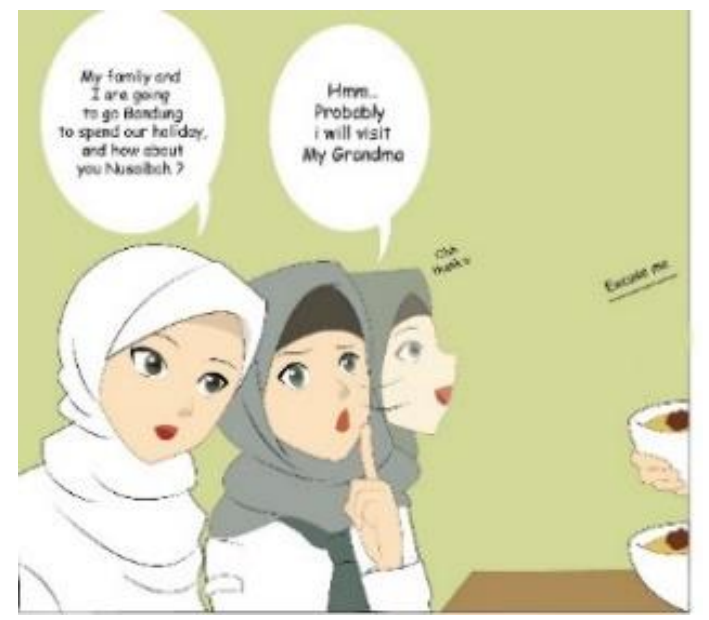

Gambar 2. Future tense( to be going to and will) Sumber : Pribadi

Pada gambar ke 2 Adreena yakin betul bahwa ia akan pergi ke Bandung untuk menghabiskan liburan, sementara Nusaibah akan pergi mengunjungi nenek namun ia belum yakin pasti pergi ke rumah nenek atau tidak. Dalam percakapan tersebut terlihat penggunaan future tense ( to be going to dan will).

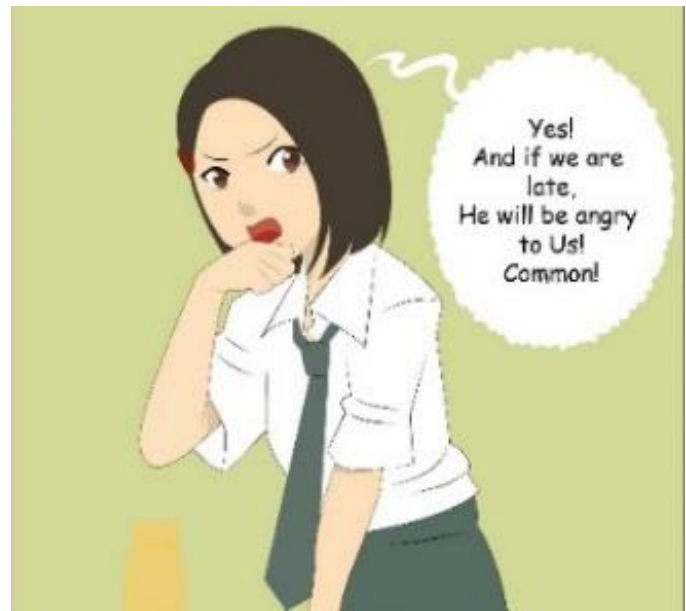

Gambar 3. Future tense(will and to be going to) Sumber : pribadi

Pada gambar 3 jelas penggunaan will digunakan oleh siswa untuk menerangkan 
bahwa "Apabila mereka terlambat Bapak guru kemungkinan akan marah, dan mereka belum tahu pasti bahwa Bapak Harun akan marah atau tidak.

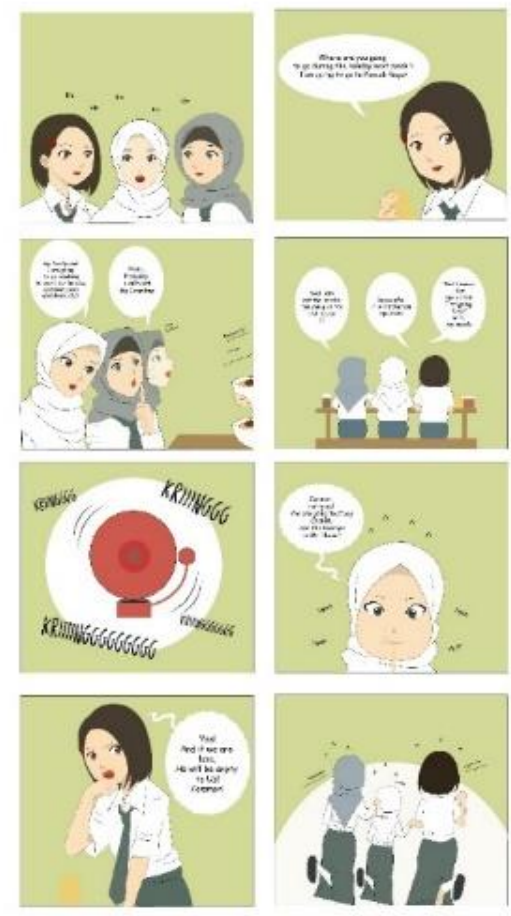

Gambar 4. Comic strip tampak keseluruhan Sumber:Pribadi

Pada gambar no 4 ialah bentuk keseluruhan comic strip yang digunakan dalam materi future tenses. Comic strip ini dibuat 8 panel dengan karakter yang cukup familiar dengan kehidupan remaja, yaitu karakter anak SMA. Dalam cerita tersebut disisipkan materi future tense yang dibedakan menjadi will dan tobe going to. Terdapat 5 kalimat yang menunjukan future tense dalam bentuk will maupun to be going to.

\section{Hasil Penggunaan Comic Strip Dalam Pembelajaran.}

Setelah melakukan pre test dan menguji coba comic strip di dalam kelas. Kemudian peneliti melakukan test kembali (post test) untuk memastikan media pembelajaran comic strip tersebut bekerja dan berfungsi dengan baik. Penggunaan comic strip digunakan selama 1 pertemuan, kemudian data diambil minggu selanjutnya dan data yang didapat sebagai berikut:

Tabel 2. Hasil post test Mahasiswa

\begin{tabular}{|c|c|c|c|}
\hline & \multicolumn{3}{|c|}{ Post Test } \\
\hline Nomor & $\begin{array}{l}\text { kelas } \\
1\end{array}$ & $\begin{array}{l}\text { Kelas } \\
2\end{array}$ & $\begin{array}{l}\text { kelas } \\
3\end{array}$ \\
\hline 1 & 60 & 50 & 60 \\
\hline 2 & 80 & 70 & 70 \\
\hline 3 & 80 & 80 & 80 \\
\hline 4 & 90 & 80 & 50 \\
\hline 5 & 80 & 60 & 40 \\
\hline 6 & 80 & 60 & 80 \\
\hline 7 & 80 & 80 & 70 \\
\hline 8 & 80 & 60 & 80 \\
\hline 9 & 80 & 70 & 70 \\
\hline 10 & 70 & 70 & 80 \\
\hline 11 & 80 & 70 & 80 \\
\hline 12 & 80 & 70 & 80 \\
\hline 13 & 70 & 70 & 80 \\
\hline 14 & 80 & 70 & 80 \\
\hline 15 & 80 & 70 & 70 \\
\hline 16 & 80 & 80 & 70 \\
\hline 17 & 60 & 80 & 70 \\
\hline 18 & 80 & 70 & 70 \\
\hline 19 & 80 & 90 & 60 \\
\hline 20 & 80 & 70 & 70 \\
\hline 21 & 70 & 70 & 70 \\
\hline 22 & 80 & 70 & 60 \\
\hline 23 & 80 & 70 & 70 \\
\hline 24 & 80 & 80 & 70 \\
\hline 25 & 80 & 70 & 50 \\
\hline 26 & 80 & 70 & 90 \\
\hline 27 & 80 & 70 & 70 \\
\hline 28 & 70 & 70 & 60 \\
\hline 29 & 80 & 70 & 70 \\
\hline 30 & 80 & 70 & 80 \\
\hline 31 & 70 & 70 & 70 \\
\hline 32 & 60 & 70 & 80 \\
\hline 33 & 80 & 80 & 80 \\
\hline
\end{tabular}




\begin{tabular}{|r|r|r|r|}
34 & 70 & 80 & 80 \\
\hline 35 & 70 & 80 & 60 \\
\hline 36 & 70 & 80 & 50 \\
\hline 37 & 60 & 80 & 70 \\
\hline 38 & 60 & 80 & 90 \\
\hline 39 & 70 & 80 & 60 \\
\hline 40 & 70 & 70 & 80 \\
\hline Jumlah & 3010 & 2900 & 2820 \\
\hline Rerata & 72,75 & \multicolumn{2}{|l}{} \\
\hline
\end{tabular}

Dari hasil test tersebut diambil dari tiga kelas yang masing - masing terdiri dari 40 siswa dengan jumlah seluruhnya 120 siswa ditemukan data bahwa ada peningkatan pada nilai test terhadap materi future tense. Rerata nilai meningkat sebanyak 18 angka yaitu dari angka 54 ke angka 72. Pada data pengambilan nilai sebelum menggunakan comic strip sebagai media belajar ditemukan sebanyak 31 yang nilainya di bawah 60, dan setelah menggunakan comic strip tersisa 5 anak yang nilainya dibawah 60 . Hal ini menunjukan bahwa media comic strip memberikan dampak positif pada hasil belajar siswa.

Tidak hanya berpengaruh terhadap hasil belajar seperti yang ditunjukan data di atas yaitu meningkatnya hasil rata-rata mahasiswa setelah penggunaan media comic strip di dalam kelas tetapi berpengaruh pada atmosfer kegiatan belajar mengajar. Dari hasil wawancara hampir seluruh mahasiswa merasa senang dalam mempelajari future tense melaui comic strip.

\section{PENUTUP}

Setelah dilakukan penelitian, pengambilan data, pengolahan data maka dapat ditarik kesimpulan mengenai pengunaan media pembelajaran comic srip pada materi future tense yaitu:
1. Media yang digunakan selama ini masih belum mampu meningkatkan semangat serta hasil yang kurang memuaskan. Hal ini dapat dilihat dari hasil data yang diambil berupa nilai dan hasil wawancara secara individual kepada mahasiswa.

2. Ditemukan 31 mahasiswa yang mendapat nilai di bawah 50 pada hasil pretest dengan rerata 54 .

3. Ditemukan 5 mahasiswa yang masih mendapatkan nilai dibawah 50 , dengan rerata nilai 72 .

4. Comic strip yang dibuat delapan panel sebagai media pembelajaran baru kekinian dari yang telah ada mampu memberikan dampak yang positif, yaitu : (1) mampu meningkatkan ketertarikan mahasiswa dalam mempelajari bahasa inggris karena dikemas dalam media yang menarik, (2) meningkatkan hasil belajar mahasiswa hal ini ditandai oleh meningkatnya hasil test setelah diaplikasikan media comic strip di dalam kelas dengan rerata 54 pada awal test menjadi 72

5. Comic strip media pembelajaran yang mampu diaplikasikan pada bidang ilmu yang lain, serta penggunaanya yang sangat mudah.

Saran untuk penelitian ini, yaitu :

1. Bagi para peneliti lain diharapkan meneliti media pembelajaran mulai dari sekolah dasar, guna menyempurnakan penelitian ini.

2. Bagi para pendidik diharapkan mengganti media pembelajaran yang lebih menarik bertujuan meningkatkan ketertarikan siswa dalam belajar.. 


\section{REFERENSI}

Arsyad, A.(2013). Media Pembelajaran. Nurul Hidayah, Rifky Khumairo Ulva. (2017). Jakarta: PT. RajaGrafindo Persada

Djamarah, S.B \& Zain,A (2006). Strategi Belajar Mengajar. Jakarta: Rineka Cipta.

Davison, R. M., Martinsons, M. G., Kock N., (2004), Information Systems. Journal Principles of Canonical Action Research 14, 65-86.

Firda Maghfirah, Herowati.(2017). Pengembangan Media Komik strip sains "Pemanasan Global" Untuk meningkatkan Motivasi membaca Siswa kellas VII SMPN 2 Sumenep. Jurnal Lensa (Lentera Sains): Jurnal Pendidikan IPA.7(2):76-84

Gunawan, (2004). Makalah untuk Pertemuan Dosen UKDW yang akan melaksanakan penelitian pada tahun 2005, URL : http://uny.ac.id, diakses 9 January 2014

Karmiani, S. (2018). Penggunaan Media Komik Berbahasa Inggris Sebagai Upaya Meningkatkan Kemampuan Membaca Pemahaman Bahasa Inggris Pada Kelas VIII SMPN 3 Teluk Kuantan. Jurnal PAJAR (Pendidikan dan Pengajaran) Program Studi Pendidikan Guru Sekolah Dasar FKIP Universitas Riau, 2(6):883-890 